\title{
Living up to the value agenda: the empirical realities of through- life value creation in construction
}

This is a pre-print version of the article: Leiringer, R., Green, S.D. and Raja, J.Z. (2009). Living up to the value agenda: the empirical realities of through-life value creation in construction. Construction Management and Economics, 27(3), 271-285.

The article is available at:

http://www.tandfonline.com.eproxy1.lib.hku.hk/doi/pdf/10.1080/0144619080269 $\underline{9032}$

\begin{abstract}
Current research agendas are increasingly encouraging the construction industry to operate on the basis of 'added value'. Such debates echo the established concept of 'high value manufacturing' and associated trends towards servitization. Within construction, the so-called 'value agenda' draws heavily from the notion of integrated solutions. This is held to be especially appropriate in the context of PFI projects. Also relevant is the concept of service-led projects whereby the project rationale is driven by the client's objectives for delivering an enhanced service to its own customers. Such ideas are contextualised by a consideration of broader trends of privatisation and outsourcing within and across the construction industry's client base. The current emphasis on integrated solutions reflects longterm trends within privatised client organisations towards the outsourcing of asset management capabilities. However, such trends are by no means uniform or
\end{abstract}


consistent. An in-depth case study of three operating divisions within a major construction company illustrate that firms are unlikely to re-orientate their business in response to the 'value agenda'. In the case of PFI, the tendency has been to establish specialist units for the purposes of winning work. Meanwhile, institutionally embedded operating routines within the rest of the business remain broadly unaffected.

KEYWORDS: servitization, integrated solutions; PFI; value, outsourcing

\section{INTRODUCTION}

There is currently extensive discussion exhorting the construction sector to compete on the basis of 'added value' rather than cost efficiency (Saxon, 2005; Levitt 2007; ASCE, 2007). Such exhortations reflect the concept of 'high value manufacturing' which has shifted the debate within the manufacturing sector away from narrowly-construed production efficiency towards the need to generate significant value externally (cf. Livesey, 2006). The concept of high value manufacturing builds on an established literature encouraging manufacturing companies to move beyond product delivery to offer through-life service provision (e.g. Slywotzky and Morrison, 1997; Wise and Baumgartner, 1999; Oliva and Kallenberg, 2003). Companies are advised to abandon existing business strategies in favour of providing 'high value' solutions through the integration of products and services (Foote et al., 2001). Of central importance is the required switch in emphasis from selling generic products towards developing the capability to address customers' unique requirements (Miller et al. 2002; Davies 
2004). Brady et al. (2005a) highlight how the trend towards the provision of integrated solutions is becoming increasingly noticeable in construction, apparently with major implications for the future modus operandi of construction firms. Saxon (2005) embraces the idea of integrated solutions as part of his vision of UK construction as a 'value centred' industry. Such ideas have a particular resonance with PFI-type procurement approaches that seek to combine responsibility for facility design, construction and operation (cf. Davies and Salter, 2006).

The purpose of this paper is to explore the extent to which the preceding ideas of competing on the basis of through-life value play out in practice. The concept of integrated solutions is initially positioned against the broader literature on servitization. Particular emphasis is given to the notion of 'service-led' projects and the capabilities that firms supposedly require if they are to enact serviceorientated business models. Attention is also drawn to the dynamic relationship between internal capabilities and the external environments within which firms operate. The second part of the paper highlights some of the broader trends that characterise the context within which the case study company operates. The extent to which construction clients have outsourced their asset management capabilities is held to be a crucial determinant of whether or not supply-side firms can sell 'solutions' to their customers. Particular insights are gained by considering longterm shifts in highway procurement in the UK and the evolving context of the Private Finance Initiative (PFI) market. The third part of the paper presents a case study of three operating divisions within a major construction company. The implications are then discussed with a particular emphasis on the way in which 
sensemaking narratives are shaped by the different environments within which the three divisions operate. An underlying methodological touchstone is provided by Pettigrew’s (1997) focus on the need to understand organisational strategy as an unfolding process embedded in context.

\section{BACKGROUND LITERATURE REVIEW}

\section{Servitization in manufacturing}

Significant attention has been given to the increasing tendency of manufacturing firms to expand into service provision (e.g. Wise and Baumgartner, 1999; Miller et al., 2002; Gebauer and Friedli, 2005). This trend is supported by an extensive prescriptive literature that exhorts manufacturers to integrate services into their core product offerings (cf. Oliva and Kallenberg, 2003). Numerous sources also suggest that moving from product delivery to the provision of integrated bundles of products and services requires a significant transformation in the ways that firms are organised (e.g. Galbraith, 2002; Sawney et al., 2004; Auguste et al., 2006). However, there seems to be an underlying assumption that such processes of servitization (cf. Vandermerwe and Rada, 1988) are initiated by senior management on the basis of economic imperatives. There is little recognition that these strategies may emerge from localised responses to changing environments.

Trends towards servitization have apparently required firms such as IBM, Nokia, GE and Rolls-Royce to re-organise themselves into ‘front-facing' and 'backfacing' business units (Macmillan and McGrath, 1997; Eisenstat et al., 2001; 
Sawney et al., 2004; Auguste et al., 2006). The basic advice offered is that frontend units should be established to manage all interface activities with the customer. Traditional production and service divisions are hence downgraded into supporting back end units. Foote et al. (2001) argue that this frequently requires long-established product units to ‘swallow their pride' and re-orientate their activities. For example, back-end units are often asked to sacrifice established channels-to-markets and customer relationships. Re-organising for servitization therefore inevitably enhances the status of some business units whilst decreasing the status of others.

\section{Different context, new capabilities}

Notwithstanding the above, there is also a more nuanced literature that suggests that the way companies re-organise themselves to become providers of integrated solutions is not entirely straightforward (e.g. Davies 2004; Davies and Hobday, 2005; Hobday et al., 2005). This second strand of literature emphasises that 'added value' is created through customising solutions that accord to specific customer needs. However, this is not seen to be achieved simply by adding services to complement core product offerings; integrated solution provision may also require firms to take over activities previously performed by their customers (Brady et al., 2005a). Davies and Hobday (2005) further emphasise the need for firms to develop or acquire new capabilities if they are to compete in what is seen to be a very different marketplace. The required capabilities are contended to coalesce around four key areas: systems integration, operational services, business consulting and financing (cf. Davies, 2004). Brady et al. (2005b) further assert that the core capability for the provision of integrated solutions is systems 
integration. Or, in other words: the capability to design and integrate disconnected sub-systems into a functioning system specific to the needs of the customer.

In no small way, the arguments developed above are rooted within a broader body of work relating to ‘complex products and systems’ (CoPS) (cf. Davies and Hobday, 2005). In essence, CoPS comprise high-technology and high-cost capital goods, and as such are seen to differ fundamentally from mass-produced products. Examples commonly cited include: telecommunications systems, flight simulators, high-speed trains, air traffic control systems, intelligent buildings, missile systems, aircraft and baggage handling systems (Davies, 2004). For the construction sector, the advent of PFI is held to have rendered the concept of CoPS especially relevant. Of particular significance is the way in which responsibilities for finance, design, construction and operation of complex facilities are (at least in theory) accepted by private sector consortia (cf. Davies, 2003; Davies and Hobday, 2005). Much is also made of the revised context within which firms involved in such consortia are required to operate. Of further note is the fact that the design and implementation of CoPS are usually delivered through major projects characterised by temporary multiple organisations (TMOs). These differences are seen to have far-reaching implications for a range of issues, including: patterns of innovation, competitive strategies, market characteristics and managerial constraints (Hobday, 1998).

\section{Driven by downstream service delivery}

Also of relevance is the concept of service-led projects introduced by Alderman et al. (2002). These are seen to provide a radically different context where the whole 
rationale for the project is driven by 'the client's business strategy and objectives for a new or enhanced service to its own customers'. Ivory et al. (2006) argue that service-led projects introduce a new realm of project complexity given the way in which the number of stakeholders increases exponentially. It is further argued that these projects involve not just a combination of construction and services, but the recognition of a vision that is driven by downstream service delivery. Such ideas find a ready resonance with exhortations for the construction sector to:

‘...add value for customers and society by shaping and delivering to meet their needs' (Saxon, 2005).

It is notable that Saxon's rallying call seemingly applies to the industry at large, rather than to any particular specialist niche which deals with high-technology CoPS such as 'intelligent buildings'. However, he does explicitly link PFI with the provision of integrated solutions and the opening up of new business models for life-cycle value creation. Saxon's suggested mission for the construction sector is further notable for its inclusion of 'society' alongside habitual customers, thereby representing a marked departure from the 'cult of the customer' that has long since dominated the discourse of sector improvement - at least since the Egan report (DETR, 1998). Indeed, in many respects the iconic status of the customer has been progressively replaced by the so-called 'value agenda', which is strong on rhetorical appeal but rather less strong on shared meaning. Of further note is the way in which stakeholders are fashionable once again, although value is seemingly still promoted as a measurable commodity which is subject to maximisation. The revised vision for the construction sector undoubtedly has 
persuasive appeal but there is little recognition of the difficulties that individual firms face in making such a transition. Brady et al. (2005b) adopt Saxon’s (2002) vision for construction as their starting point in considering whether integrated solutions business models can work in construction. They place particular emphasis on PFI/PPP projects which are driven, it is claimed, by a localised vision of downstream service delivery (see also, Tranfield et al. 2005). Ivory et al. (2006) further point towards the need for alternative perspectives to enable practitioners to make sense of the emerging complexity that characterises serviceled projects. They suggest sensemaking as one such a perspective. Despite receiving considerable attention within the strategic management literature, sensemaking as yet remains under-represented within the project management literature (cf. Thomas, 2000; Thiry, 2001). In essence, sensemaking is not concerned with static representations of organisations, but with processes of enactment (cf. Weick, 2001). Hence it is the processes through which integrated solutions are enacted and contested that are central to understanding. The same argument can be applied to the concept of 'value' which lies at the heart of Saxon's (2005) vision of integrated solutions in construction. Rather than allude to the construction industry's lack of a common understanding of value, an alternative perspective informed by sensemaking would accentuate the variable and multiple representations of such concepts. Of particular interest would be the way in which they are continuously contested, deconstructed and negotiated.

\section{Capabilities in a changing environment}

In emphasising the capabilities that are necessary for integrated solutions, Davies and Hobday (2005) allude to the dynamic interplay between a firm’s internal 
capabilities and changing external conditions. They further suggest that the greater the rate of change in the external environment, the more important a firm's internal resources and breadth of capabilities are to its long-term success. Davis and Hobday (2005) further refer to the concept of dynamic capabilities, as advocated by Teece et al. (1997). The dynamic capabilities literature suggests that it is not a firm's resources themselves that are important, but the ability to reconfigure embedded operating routines to enable responses to changing environments (Teece and Pisano, 1994; Teece et al., 1997). Davies and Hobday (2005) also acknowledge that organisational responses are path dependant. The contention is that the strategic alternatives available to a firm are a function of its current position, which in turn is shaped by the path it has travelled (Teece et al., 1997). Firms are therefore subject to a degree of structural inertia and are constrained in part by previous investments and established routines (cf. Hamel and Prahalad, 1994).

It follows from the above that the ways in which firms conceptualise and enact integrated solutions will be shaped by the broader environment within which they operate. Furthermore, such sensemaking processes would continually adjust to the dynamics of the localised operating environment. Different operating units are likely to structure themselves differently in accordance with the demands of different environments (cf. Lawrence and Lorsch, 1967). In consequence, it is to be expected that actors across different operating units will accord different degrees of relevance to notions such as 'integrated solutions' and 'service-led projects'. Indeed, many construction companies continue to be highly decentralised such that different operating divisions are shaped by very different 
path dependencies. Such insights once again challenge the image of a centralised top management that instigates a shift from one steady state to another. Organisations are indeed perhaps more realistically conceptualised as being in a continuous process of flux and transformation in the sense advocated by Tsoukas and Chia (2002).

\section{UNDERSTANDING THE PROCUREMENT CONTEXT}

\section{Privatisation and outsourcing within the client base}

In terms of understanding the broader context, it is especially important to position the persuasive appeal of integrated solutions against long-established trends of privatisation and outsourcing within client organisations. Brady et al. (2005a) cite the role of government-led reforms such as privatisation, deregulation and liberalisation in extending the use of Build Operate Transfer (BOT) procurement during the 1990s. What they fail to mention is that the newly privatised companies frequently embarked upon extensive downsizing programmes in order to make themselves competitive in the marketplace (Bishop et al., 1994). For present purposes, the important point is that many such downsizing programmes were often accompanied by the outsourcing of clients' in-house asset-management capabilities. The exemplars of this trend were the water utility companies (Davidson, 1990; Ogden, 1995; Cooke, 2003). Such outsourcing strategies were driven by a range of factors, including regulatory pressures and the introduction of yardstick competition (Cowan, 1994; Ogden, 1995). In no small way, it was these trends that created the space for the private 
sector to offer integrated solutions in response to specified business needs. But such developments were by no means uniform, or even consistent. While some water utility companies outsourced asset management capabilities, others retained them in-house. Localised decisions were influenced by the regulatory standards set by The Water Services Regulation Authority (OFWAT) at five-yearly intervals. Some chose to outsource selected capabilities, but to retain others they considered to be strategically important. Many water utility companies have tended to oscillate between outsourcing and bringing capabilities back in-house again. What is clear is that neat-and-tidy generalisations are difficult to sustain. The overall picture is one of vicissitude; the end result is that contractors endeavour to sell ‘value-adding’ integrated solutions to some clients, whilst offering traditional 'build-and-run' contracting to others. Such oscillations within the client base once again militate against any notion of a shift from one steady state to another.

\section{The changing context of highways procurement}

Of particular relevance to the selected case study company are long-term changes in highway procurement and the changing role of the Highways Agency (HA). The HA was established in 1994 with the remit of managing and maintaining the motorway and trunk road network (Haynes and Roden, 1999). Its role has since evolved into that of network operator with the declared mission of enabling 'safe roads, reliable journeys and informed travellers'. Since its formation, the HA has progressively adopted a regional procurement policy whereby they have contracted with fewer and fewer contractors. Initially, there were 91 agency agreements, of which 85 were with local authority highway authorities. By 1996 
the number of agency agreements had been reduced to 24 , which in turn has since been reduced to 14 maintenance areas.

The decreased reliance on local authority highway authorities equates in no small way to the progressive privatisation of the nation's highway maintenance capability. This trend has been further accentuated by central government pressures towards market testing and compulsory competitive tendering (CCT) which encouraged local authorities to outsource their local highway maintenance work. Such trends frequently resulted in highway maintenance divisions within major contractors being comprised entirely of TUPE ${ }^{1}$-transferred operatives. Such divisions would see themselves from the outset as involved in the provision of highway maintenance services.

The progressive privatisation of highway maintenance capabilities has been accompanied by an espoused commitment to 'collaborative partnerships'. This is especially notable within the HA’s evolving procurement policy (Highways Agency, 2005). The private sector has in turn increasingly aligned itself with the HA's stated mission of providing 'safe roads, reliable journeys and informed travellers' thereby creating opportunities for incentivised performance-based contracts. Progress towards collaborative working in the delivery of the HA's mission remains curtailed by a lack of trust of public and private sectors. A critical inhibiter is the public sector's inability to issue long-term contracts as a consequence of the centrally imposed need for frequent market testing. Nevertheless, a succession of procurement initiatives such as Early Contractor Involvement (ECI) and the Managing Agent Contractor (MAC) contract have 
been inching towards a more service-orientated engagement between public and private sectors. MAC contracts were typically awarded for 5-year periods, although these have recently been supplemented by Extended Managing Agent Contractor (EMAC) contracts which can be renewed for an additional 2 years subject to performance. Other significant initiatives which characterise the changing interface between the HA and contracting firms include the HA's Capability Assessment Toolkit (CAT) and Culture Assessment Framework (CAF) (Highways Agency, 2005). These initiatives seek to develop a 'best value' culture based on partnerships with performance measurement and continuous improvement being key features. The net result of these changes has been to concentrate highways maintenance contracts with a small number of large contractors.

\section{The evolving context of the Private Finance Initiative}

Contracting firms seeking continuously to align themselves with Government procurement policies have also been required to respond to the ever-changing nature of PFI. The PFI market has continued to evolve since its creation in 1992; this applies both to its magnitude and to the rules of engagement (cf. Spackman, 2002; NAO, 2007). In terms of scale, the initiative has expanded since its launch in 1992 to comprise $10-15$ per cent of the annual public sector investment in capital procurement (HM Treasury, 2006). At the beginning of 2007, over 750 projects had been signed with a combined capital value exceeding $£ 55$ billion (NAO, 2007). As such, PFI represents a significant proportion of the overall UK construction market. Several of the larger contractors are now routinely engaged in bidding for long-term PFI concessions that involve the financing, design, 
construction and operation of assets previously managed within the public sector. This is especially true in niche markets relating hospitals, prisons, schools and major roads. However, it is possible to overstate the impact of PFI; opportunities to take leading roles in PFI projects tend to be limited to a small number of large firms. Projects are characterised by significant barriers to entry and firms need substantial capital resources to carry the cost of bidding. Most players in the PFI market also continue to operate in more traditional construction markets at the same time, thereby emphasising the need to play two games. Many contractors have formed dedicated front-end units to manage the PFI bidding process. Such units have much more in common with City investment firms than they do with traditional construction companies. Nevertheless, the extent to which the creation of such front-end units impacts upon the operating routines of established business divisions is debatable. Indeed, the construction division within PFI contractors invariably approach projects as they would any other construction job; institutionally embedded routines are not so easily unpicked (Leiringer, 2006).

As already noted, PFI has continued to evolve since its inception. Following its initial launch in 1992, it was subsequently re-launched in 1993 and again in 1995. Indeed, there has been a continuous flow of governmental reviews, policy documents and evolving guidelines ever since its inception (e.g. Bates, 1997; Bates, 1999; HM Treasury, 2000; HM Treasury 2003; HM Treasury, 2006). Furthermore, PFI has been continuously shaped by successive EU procurement directives, the most recent of which requires the mandatory use of 'Competitive Dialogue Procedure' for complex projects (NAO, 2007). In the specific contexts of schools and hospitals, the currently advocated approaches are very different 
from previous manifestations of PFI. 'Building Schools for the Future' (BSF) allegedly represents the greatest investment in schools for half a century. It reportedly involves more than 3500 schools across 150 local authorities, with an estimated state contribution of $£ 45$ billion in capital funding and PFI credits (Education and Skills Committee, 2007). BSF is especially notable for its insistence on the formation of joint ventures involving the central government delivery agency ‘Partnership for Schools’ (PfS) together with the residing local authority. Similar developments have also been taking place in the context of healthcare, whereby a Local Improvement Finance Trust (LIFT) is established as a limited company. Shareholders include the local NHS Primary Care Trusts (PCTs) and Partnerships for Health (PfH) as well as private sector firms. The socalled 'LIFTco' then owns and maintains the building and leases the premises to the PCTs. It would therefore be the LIFTco which would seek to operationalise notions such as integrated solutions and service-led projects for the purposes of 'maximising value'. Such developments represent a significant shift away from previously established PFI models, and further blur the boundaries between the public and private sectors. Of particular significant is the way in which individual private-sector firms must build the requisite capabilities in conjunction with others. This is not something they can do in isolation.

\section{RESEARCH DESIGN}

In essence, the research sought to access the empirical realities which pattern and condition the way in which through-life value creation is conceptualised and enacted. A qualitative in-depth case study method (cf. Eisenhardt, 1989; Flyvberg, 2007) was adopted as part of a prolonged engagement with a major construction 
company. The case study extended longitudinally over a period of two and a half years. The company investigated (hereafter referred to as Conco) is a leading PFI contractor in the UK market. It has an expressed policy of embedding investments for the long term and is a key member of a number of PFI concessionaire brands.

Given the tendency of construction companies towards de-centralised operating structures, it was decided at the outset that useful insights could be gleaned from comparing and contrasting across different operating divisions. Conco itself is essentially a holding company comprising more than 20 operating divisions, many of which have a presence in the UK market. Three of these were included in the case study:

(i) Conco Civil Engineering Limited (CCEL);

(ii) Conco Highway Solutions Limited (CHSL);

(iii) Conco Private Finance (CPF).

The case study was initially developed through a series of discussions with three senior managers with strategic responsibilities for business development in the three selected operating divisions. Drawing from the relevant literature reviewed above, a conceptual framework was designed to guide data collection (cf. Miles and Huberman, 1994). This was initially of a tentative nature as we specifically avoided trying to constrain the research by imposing predetermined theoretical perspectives (Eisenhardt, 1989; Orton, 1997). The research approach thereafter was primarily abductive in that we adopted an iterative approach between emergent data and sensemaking frameworks derived from the literature (cf. Dubois and Gadde, 2002). Several literature sources reviewed above relating to the changing construction context were only deemed relevant in response to empirical findings. Emergent data were progressively incorporated into the analysis allowing for systematic combining of the emerging issues and ongoing 
development of the interview templates (cf. Eisenhardt, 1989; Dubois and Gadde, 2002).

Informal discussions with the three senior managers continued throughout the duration of the research. Data collection methods included multiple visits to numerous corporate offices and project locations. Archival analysis of relevant unpublished sources also provided useful insights, but of prime importance were 23 semi-structured interviews conducted with senior managers across the three selected operating divisions. The duration of the interviews varied from 60 to 150 minutes. The level of seniority of the interviewees ranged from operational managers to managing directors. Reviews were also made of public sector procurement policies, with a particular emphasis on the extent to which they were encouraging the construction sector to compete on the basis of through-life value. Discussions were also held with a variety of client bodies and six lengthy semistructured interviews were undertaken with representatives responsible for procurement. This enabled a richer understanding of the external pressures on Conco and the procurement landscape in which the company operates. A research log was kept throughout the research period and all data sources were formally recorded. Throughout the two-and a-half year period the persuasiveness of emergent findings was continually tested through feedback sessions with senior representatives of the three operating divisions. Generalisability has been further enhanced through several open industry seminars where the broader relevance of the central arguments has been tested.

\section{CASE STUDY}

\section{Overview}

Conco plc is one of largest international construction companies operating in the UK with an annual revenue in excess of $£ 4$ billion. It is also a leading contractor in the PFI market with experience dating back to when the initiative was first 
launched. At the corporate level the stated aim is to work collaboratively with sophisticated customers to achieve their needs while achieving the highest levels of quality. The company undoubtedly has a strong brand and an enviable reputation for the delivery of large, complex construction projects. Even so, senior managers concede that the company as a whole tends to be perceived as conservative and dependable, but not especially exciting or innovative. The company's corporate marketing policy is currently seeking to overcome this perception by emphasising the organisation's commitment to innovation. Similarly to its peers, Conco has traditionally operated on the basis of a devolved corporate structure. It remains characterised by decentralisation with considerable localised autonomy for its constituent operating divisions. The majority of the company's revenue derives from the creation and care of large-scale public infrastructure, plus private sector asset upgrade and maintenance. Internally, the de-centralised structure is considered to be both a strength and a weakness. The policy of decentralisation was repeatedly portrayed as having been crucially important to the company's success. But there is also recognition that the company as a whole 'punches below its weight' and that cooperation between the operating divisions is not as strong as it could be:

Increasingly, I think we are having to face up to more demanding clients, and the result is that there is more reason, in some ways, than perhaps in the past, for the operating divisions to talk to each other, because, I think, actually, the challenges are starting to become more common. I think it's interesting; it is still, to a great extent, client driven. [Director CHSL] 
The strategy of ceding significant autonomy to operating divisions is seen to be important to enable them to make business decisions that are appropriate to the markets within which they are positioned. A direct consequence of the decentralised structure is that individual operating divisions frequently possess their own distinct cultures. Such differences are exacerbated by the fact that the structure of the company is in no small way shaped by a string of previous acquisitions. Some of the acquired companies continue to trade under separate brands. Nevertheless, Conco as a whole aspires to integrate the often disparate activities of the individual operating divisions. Yet, as the managing director in one of the operating divisions observed:

[this] can be fraught with difficulties, because there may be conflicts that arise between what the individual business wants to do and what the holding company wants to do. But I think having a strong business-centred culture has been central to the success story of [Conco] and I think it's a case of retaining that, but looking at ways of making sure there are cross-cutting synergies that can be had. And that's all about how you, then, incentivise those individual businesses to participate in wider ventures.

It would therefore seem that the integration of different internal business units into joint endeavours on behalf of the company as a whole cannot be taken for granted. 
This would apply equally to the provision of integrated solutions as it would for any other collective undertaking.

\section{Civil Engineering Limited}

CCEL is in many respects the epitome of a traditional civil engineering company with an enviable track record in winning high-profile projects. By their own admission, managers within CCEL see themselves as somewhat isolated from other operating divisions: "we work in our own little world, building the product". The strong engineering culture was described as something which is continuously celebrated. Key capabilities were seen to centre on traditional project management controls, with a particular emphasis on budgeting, programming and cost reporting. Managers within CCEL see themselves as engineers operating within the 'real world', which they contrast with the heady world of finance within Conco Private Finance (CPF). They also see themselves as having a distant relationship with Conco Highway Solutions Limited (CHSL), which they perceive as operating in a less deadline-orientated environment. As such, employees in CCEL have a very strong shared identity. In the words of one interviewee:

"I think it's important that we maintain our identity and we don't diversify to purely a service provider type of organisation. I think it's important that we recruit good civil engineers who want to build and construct things and improve things."

[Operations Director] 
Particular pride is taken in CCEL's ability to deliver complex projects.

Accordingly much is made of organisation's track record which is seen as an important differentiator. However, the interviewees also recognised that in the past they have been seen as hardnosed and aggressive. They justified this with reference to the commercially aggressive environment of the 1980s and early 90 s which was seen to favour those with the ability to maintain commercial positions. But the interviewees were consistently keen to emphasise that the culture is changing as CCEL seeks to be more customer-focused with a greater emphasis on collaborative relationships with both clients and sub-contractors. The division sees itself as having been being predominantly responsive to the evolving demands placed on the construction sector over the last few decades. This relates especially to shifting procurement policies; the current vogue for through-life value is seen to be no different. This responsive mode of operation is aptly illustrated by the Head of Business Development with reference to the changing procurement agenda for highway construction:

"Lots of other ideas have come from Government and indeed the way they procure things, whether it be ECI, whether it be Design and Construct contracts, whether it be the CAT, you know all these things. We then quickly respond and adapt to serve it back up to the client and say: 'We're doing this; this is exactly what you want, we think, and we're ready'.... On the one hand we're very conservative, on the other hand, you know, we're struggling to be flexible and a bit fleet of foot." 
The above quote sums up well the ongoing struggle as firms of this nature continuously seek to position themselves against emergent procurement initiatives. It was also recognised that any reorientation towards more collaborative ways of working challenges deeply ingrained practices. Furthermore, any shift towards collaborative working was considered to be dependent upon a similar willingness to engage differently from within their clients. It was argued that this could not be taken for granted, especially at the operational level. In consequence, two distinct cultures were seen to currently coexist within the division. The first is much more deeply embedded and focuses on the delivery of the finished product, with a heavy emphasis on engineering expertise and core project management skills. The second is much more recent and emphasises the importance of stakeholder management. Managers felt that they were required to oscillate between these different modes of behaviour, frequently on a project-to-project basis. However, neither mode of working was characterised by any claim to be offering integrated solutions. The notion of 'service' was frequently mobilised in the context of collaborative working, but only in the sense of 'giving good service' in the delivery of projects. There was little evidence of any degree of empathy with the concept of through-life service provision.

The obvious sense of pride that CCEL employees take in their capability of delivering complex projects is also reflected in how they see their role in the bidding for PFI work. As explained by an Operations Director: 
I think [CPF] exists because of the delivery and the credibility of

CCEL and the regional businesses to deliver schemes successfully. Clients, when they're letting a PFI, have got to be comfortable that the delivery part of the concession is going to deliver and we've got, you know, increasingly a track record and a long history in [Conco] of delivering, and that's important, I think, to clients.

In summary, CCEL is largely unaffected by current debates about integrated solutions and associated ideas about 'high-value' construction. Indeed, several interviewees appeared overtly hostile to the idea that Conco as a whole should shift its focus to services. Certainly CCEL cannot be construed as a back-end business unit which is being forced to swallow its pride; they continue to operate much the same today as they ever did. CCEL is a highly self-confident business with a strong sense of self-identity. Managers within CCEL make little attempt to echo the rhetoric of the 'value agenda'; but they are highly persuasive in portraying what they do as high-value activity. They are also crucially aware of the importance of their reputation in the marketplace. There is little doubt that Conco as a whole benefits from CCEL's established track-record of delivery.

\section{Highway Solutions Limited}

The core expertise of CHSL was originally in the provision of road maintenance services. The division was created in the 1990s and has since secured several long-term term maintenance contracts with a variety of local authorities. However, CHSL's most significant client is undoubtedly the Highways Agency (HA), for whom they aim to provide an integrated asset maintenance service. In 
short, CHSL aspires to move from a term maintenance contractor to an 'allsinging' service provider. In this respect they see themselves as highly serviceorientated and focused on the needs of the end-customer:

\author{
I don't think there's anybody in the road maintenance industry \\ now who can say, well, we're just going to stick to mending \\ roads. [Commercial Strategy Manager]
}

In contrast to traditional contracting firms, CHSL does not operate within a project-based environment and is therefore less prone to short-term fluctuations in demand. Operational activities range from winter maintenance and road resurfacing right through to incident response technology and geographical information systems. CHSL has enjoyed rapid recent growth and has successfully positioned itself in the marketplace. Of particular note is their ability to form joint venture partnerships with leading engineering design consultants to fulfil the role of 'Managing Agent Contractor' (MAC) for the HA. Senior managers within CHSL see their key capabilities to include the delivery of complex multidisciplinary contracts; but they also put much emphasis on their ability to put together successful bids. Certainly their capabilities have evolved significantly from their origins in securing specific road maintenance contracts that were essentially small civil engineering projects. Indeed, this transition is central to their sense of self-identity: 
Well, we're not a construction company. We carry out

construction work, but it is a relatively small part of what we do.

We are principally a service industry. [Managing Director]

In contrast to the industry norm, CHSL employs a large direct labour force, many of whom are TUPE transfers from local authorities. Interviewees from within CHSL were strongly focused upon the business environment within which they operate, and in consequence felt somewhat isolated from Conco as a whole. In essence, CHSL perceives itself as very different from its sister operating divisions. This sense of difference is reinforced both by its unique path dependency and the underpinning business model. In contrast to CCEL, who see themselves as a central part of Conco, CHSL employees have always been characterised by their sense of difference. Several initiatives have over the years been taken by senior management to alleviate this sense of alienation. The most significant of these was the recent complete re-branding of the operating division so that it is quite obviously part of the broader Conco group.

The sense of independence from the rest of the company is reflected in CHSL's interactions with other operating divisions. Indeed, the extent to which CHSL really is dependent upon other divisions within Conco is a contested issue. Two opposing views can easily be discerned. The first and dominant view is represented by those who firmly believe in good relationships and increased collaboration between Conco's operating divisions; this is seen to be essential in making best possible use of the company’s collective strengths and capabilities. The second is represented by those who believe that CHSL would be better off 
'going it alone', thereby emphasising the need to develop all required capabilities in-house. To many, the difficulty of liaising with other operating divisions was seen to be a problem too far. In the words of one senior manager:

Being quite open about it, at the end of the day it's just another interface that we probably don't need. So, as we're able to build up the skills in-house to cope with the work, I think that's a better way forward than subcontracting to, effectively, a third party, even though they're still part of the holding company.

Due to the longer term nature of many of its contracts, CHSL is not as sensitive to short-term fluctuations in demand as more traditional construction companies. However, their business is highly sensitive to shifting procurement policies within the HA. CHSL management further recognise that there is a limit to the number of HA areas they can secure, and as a result there is a need to be constantly on the look out for alternative business streams. This provides one of the key reasons for the interest in PFI schemes relating to the provision and operation of major highways. Within this context they consider themselves as constituting a major part of the Conco’s contract winning capability:

[CHSL] is starting to take a much more prominent role, because what matters to the client, apart from the new build, is how that new build with the rest of the network operates and it affects their customers. And so, we're going from being almost a 
subcontractor to a very major part of the winning capability.

\section{[Managing Director]}

However, at the same time there is also frustration within CHSL's senior management of not being able to convert the important role they play in winning the bid into being able to influence key design decisions. Many felt that there is a disproportionate emphasis on cost reduction during design and construction with the result that long-term operational issues were too often neglected.

In summary, CHSL displays many characteristics of a service-led producer. In contrast to CCEL, CHSL continuously strives to position itself as a 'partner' in the delivery of the HA's service-orientated mission. It is also much more externally focused and is driven to a much greater extent by ideas relating to through-life value. CHSL has undoubtedly been a major beneficiary of the privatisation of highways maintenance. Indeed, the steady and prolonged trend towards privatisation is a prime reason why the business has been able to grow so significantly. However, it is also important to recognise that CHSL's approach has been to respond to opportunities as-and-when they occur. Overall, the strategy has been predominantly emergent and opportunistic. It has not been driven by any sort of 'grand vision'. Also of note is the way in which CHSL has consistently developed new capabilities as the environment within which they operate has evolved and changed. Examples include the development of traffic management capabilities and rapid incident-response technology. While CCEL remains essentially the same as it was thirty years ago, this categorically is not true for CHSL. 


\section{Private Finance}

CPF manages a significant proportion of the Conco’s investments, currently accounting for more than $20 \%$ of its profits. The division was created in the 1990s, primarily for the explicit purpose of exploiting the PFI market. It has since experienced consistent growth, with especially rapid growth in recent years. Conco has been a key player within the PFI market since its early days, and its managers feel they have developed robust delivery mechanisms. Strong legal and financial management skills are considered to be key in-house capabilities. The CPF division is thereby characterised by a diverse set of skills that are outwith those found within traditional construction businesses. Indeed, the core capabilities of CPF have little to do with civil engineering or construction. A high proportion of CPF's employees come from non-construction backgrounds, with an especially noticeable dominance of lawyers and financiers.

A point of commonality with CCEL and CHSL is that CPF's strategy has tended to be reactive in response to an evolving market. However, an important difference exists in that CPF is explicitly tasked with taking into account the needs of the other operating divisions when deciding which projects to bid for. In no small way, CPF exists to win work for the other operating divisions within Conco. There is as such an embedded sense of belonging to the group and strong recognition that $\mathrm{CPF}$ is crucially reliant upon the other operating divisions for its success: 
"You don't get the money on the balance sheet in the first place that we can use here to invest in projects, unless it's come from the core business of the company, and that's building things... It is humbling; it puts you back with the core strategy of the company, which is to excel in its core sectors. This is a useful sideline, because the company has got some money and it leverages its own business. But, basically, the core business is the core business.” [Senior Project Finance Manager]

CPF therefore acts as the focal point behind which other operating divisions can come together and bid for projects. It acts as the primary point of contact for the client, while at the same time co-ordinating inputs from other parts of the organisation. In some respects, its role as the bidding entity means that it tends to act as a surrogate client to their sister operating divisions. CPF further resides over a sophisticated system of bidding approval processes. Robust governance structures are clearly vital given the high risks involved. However, while CPF maintains very close control over the bidding process, they ironically have relatively little influence over other operating divisions’ pricing policies. It remains the case that other operating divisions bid for work, as they would for any other project, and retain responsibility for their own bottom-line performance.

Since the formation of CPF there have undoubtedly been tensions between them and the operating divisions that are ultimately responsible for project delivery. More recently, relationships are described as getting better and are now seen to be good at a senior management level. Nevertheless, cross-company relationships 
can still be problematic at a regional middle-management level. Tensions remain especially evident during the bidding process for PFI projects, and this was seen to be inevitable:

\author{
"Every now and then someone might want to safeguard their \\ own organisation's interest more than the parent organisation's \\ interest. I think that has to do with how people are rewarded \\ and the way that incentives cascade down to the individual \\ divisions. [Bid Manager]
}

In contrast to many of its competitors, Conco's focus is on embedding PFI investments that are profitable in the long-term. This orientation towards the longterm is demonstrated by their participation in several concessionaire brands specific to particular sectors, e.g. health, roads, schools and infrastructure. Now that the PFI market has matured, there are seen to be fewer opportunities to benefit from re-financing following the completion of the construction stage. The view of senior management is that the risks and premiums associated with PFI are both likely to continue to decline as the market matures further. Although CPF sees itself as highly innovative, linked incentives are not felt to be strong enough to encourage innovation either in construction or in the provision of FM services. Furthermore, the bidding process is seen as dramatically constrained by time which limits the degree of novel or non-traditional design solutions. Projects are usually defined using long-established risk assessment techniques. In consequence, there is little scope for input from service providers into the design process. This was recognised to be something of a contradiction: 
"...because the whole basis of PFI is that [the client] is only

paying the service provider for when he provides a service,

but... a lot of the decisions that are made are out of the hands of

the service provider." [Bid Director]

The broader commercial environment has had a clear influence on how CPF has structured itself, and the balance they have struck between formal and informal routines. This reflects both the high-risk environment within which it operates, but also the ever-changing nature of the PFI process. In response to the dominant nature of the PFI process to date, relationships with clients have been primarily transactional and 'arms-length'. As such, the division has not been able to build strong collaborative relationships with its clients, despite good relations on an individual level. This has much to do with PFI governance arrangements, but also reflects the risk of sharing ideas with competitors pre-contract. However, the reliance on a mixture of formal and informal routines also reflects the shifting nature of PFI. As a result of the prevailing uncertainty surrounding the future of PFI, there is limited long-term planning. In consequence, the development of new internal routines and systems are not prioritised:

I don't see the UK Construction Industry having a consistency of procurement strategy that would lead a company like ours to invest heavily in knowledge management. In other words, things change too quickly for us to worry too much about it. [Bid Director] 
The above implies that in a rapidly developing market such as PFI, an orientation towards continuous learning is considered more important than knowledge management systems per se.

\section{DISCUSSION}

\section{Strategies are emergent, visions are contested.}

The literature relating to servitization in the manufacturing sector seems to assume that strategic decisions are made centrally by senior management on the basis of economic imperatives. It also suggests that the shift in modus operandi requires a significant transformation in the way firms are organised. However, the empirical findings suggest a more complex picture whereby strategy is predominantly emergent rather than pre-determined. Each of the selected operating divisions has been inexorably shaped by the business environments within which it operates. Furthermore, they all operate as separate profit centres, each with their own business plan, channels to market and customer relationships. In short, they possess very different path-dependencies with very different institutionally embedded operating routines. Such factors combine to militate against notions of centralised strategy in favour of localised responses to evolving opportunities. Certainly there is no strategic imperative to operate on the basis of 'customer solutions' that cuts across the three operating divisions. 
The vision of competing on the basis of through-life value undoubtedly has some purchase within CHSL and CPF. However, in both cases the constituent ideas would seem to have been appropriated by senior managers for the purposes of sensemaking rather than as explicit strategies for driving change. Certainly they are both characterised by their ability to re-configure their operating routines in response to changing environments. In comparison, CCEL is much more stable and traditional; the underlying business model is tried-and-tested and remains much as it did thirty years ago. There is little danger of CCEL 'swallowing their pride' and 'sacrificing existing channels to market'. Senior management within CCEL remain largely unimpressed with notions of 'through-life added value'. Their basic argument is that this is not what clients pay them to do. CCEL's success hinges on the fact that clients continue to offer them work because of their expertise in the delivery of large, complex construction projects. Overall, the delivery of large, complex civil engineering projects remains at the heart of Conco plc as a whole.

CPF of course was created with the specific purpose of winning work in the PFI market. As such it perhaps approximates towards the 'front-facing' business unit described in the servitization literature. However, its dealings with other operating competing remain fraught with commercial tensions. It therefore falls some way short of the idealised 'systems integrator'. In the case of CHSL, they have explicitly positioned themselves as a service provider in response to shifting procurement policies within the Highway Agency (HA). It has been the HA which has set the agenda as it has changed its focus from asset manager to network operator. CHSL has undoubtedly been very successful in adapting to this 
changing context, but its responses have been largely opportunistic rather than driven by any grand vision.

\section{Competing in a new context}

Davis and Hobday (2005) make much of the supposed radically different context provided by complex products and systems (CoPS). The argument that major projects have become much more technologically complex is undoubtedly true. Yet such contexts have been continuously evolving ever since the Industrial Revolution and have not suddenly arrived from over the horizon. It must further be recognised that the antecedents of PFI go back much further than 1992 in the form of Build Operate Transfer projects (and other variants). In the context of manufacturing, CoPS may indeed provide a very different context from that of original-equipment-manufacturers (OEMs). But in construction it is more difficult to sustain the argument that CoPS provide a context which is radically new. Certainly the challenge of delivering major projects in a context where responsibility is shared across a multi-organisational consortium has long since been familiar to those who work within construction. Likewise, projects with a service dimension can be traced back even beyond the Industrial Revolution. It would also seem that claims to compete on the basis of through-life value creation rest more on rhetoric than any sort of commercial reality.

Perhaps the main issue that is under-addressed in the literature is the way in which organisations are required to compete in several contexts at the same time. And it is this ability to adapt simultaneously to different operating contexts which is 
perhaps much more pertinent than any notion of a shift from one orientation to another.

\section{Through-life service commitments}

In contrast to many of their competitors. Conco has a clearly articulated strategy of investing in the long term. Nevertheless, on the basis of the case study, the extent to which they really are taking on through-life service commitments remains debatable. Certainly such through-life commitments do not constitute part of CCEL's operating context, which remains essentially a projects-based business. Even on those occasions when they are involved in PFI projects, they tend to operate as a subcontractor to the separately created concession company. Furthermore, the case study clearly illustrates how managers responsible for service operations invariably struggle to have any real impact on key design and construction decisions. Such decisions remain dominated by an institutionalised mindset that prioritises traditional cost cutting (euphemistically labelled 'value engineering') over any consideration of through-life operational value. Such a mindset is continuously reinforced by the ways in which construction managers are incentivised to contribute to the bottom-line of their own operating division. The same disconnect is also evident between CPF and the dedicated companies that are set up to provide aspects of ongoing service provision. CPF exists to win work and to put bids together. This is how their managers are incentivised; and once again the individuals who ultimately take responsibility for operational issues struggle to influence the key decisions. Even more telling is the observation that concession companies themselves do not take full responsibility for through- 
life service commitments. This is because the contracts with key suppliers are invariably subject to re-negotiation - typically after no more than 5 to7 years.

The 5-7 year timeframe also accords with the operational commitments taken on by CHSL in respect of their Highways Agency (HA) work. Furthermore, there seems little imminent chance of any significant increase in the duration of these commitments. Important constraining factors include the planning cycle within the HA and propensity for risk within the market place. Indeed, it is notable that the majority of the privatised utilities also remain governed by regulatory agreements which are framed around a 5-year planning cycle. The vision of competing on the basis of through-life value may well constitute an intoxicating rallying-call for the harbingers of change (cf. Saxon, 2005), but the reality is much more nuanced and constrained.

\section{Integrated solutions and service-led projects}

On the basis of the above, it is difficult to promote the case study company as an exemplar of either integrated solutions or service-led projects. Yet this should not be seen as a criticism, as the company is undoubtedly a market leader across all three of the operating divisions investigated. More generally, it must be recognised that neither of the two concepts is especially strong in terms of its empirical support within the context of construction. But then their advocates do not present them as concepts which are necessarily empirically based (cf. Brady et al 2005a; 2005b; Ivory et al 2006). Where they perhaps have more value is as prescriptive models to guide construction companies on how they might position themselves in an ever-evolving marketplace. However, there is no evidence in the 
case study company to suggest that they have been used in this way; the same point also applies to Saxon's (2005) recipe for a value-based industry. This is not to say that these various constructs have not been useful as sensemaking devices. Generic trends across all three operating divisions are few-and-far-between; and such trends as may exist are rarely clear cut. Some client organisations undoubtedly oscillate between outsourcing asset management capabilities and taking them back in-house. In response, contracting firms continuously adapt in the same way that they continuously respond to a seemingly endless progression of different procurement arrangements. Construction companies such as Conco may well not be exemplars of integrated solutions, but operating divisions such as CPF and CHSL are undoubtedly exemplars of dynamic capabilities (cf. Teece and Pisano, 1994). But at the same time, it is CCEL which remains the cornerstone of organisation and provides the ongoing stability against which other, supposedly more innovative, operating divisions can position themselves. It is CCEL which accounts for Conco's reputation for delivery and it is CCEL which is central to Conco’s brand identity.

What is clear is that trends towards servitization within firms such as Conco cannot be understood in isolation of the bigger picture. The backcloth of privatisation and outsourcing within the client base must be an active part of any longitudinal analysis. These broader changes are invariably driven by economic and political forces largely beyond the influence of individual managers. In consequence, managers within construction firms frequently feel overwhelmed by emergent complexity. In this respect the rhetoric of value-based competition provides them with a legitimising discourse to bolster their sense of self-identity. 
And the more sophisticated storylines of integrated solutions and service-led projects are mobilised primarily as sensemaking devices which transcend the messy realities of their day-to-day existence.

\section{CONCLUDING REMARKS}

This paper has sought to investigate the extent to which a leading construction company is managing to compete on the basis of through-life value. The aspiration of competing on this basis has been linked to the concept of 'high value manufacturing'. Manufacturing firms increasingly seek to compete on the basis of value by moving beyond product delivery to offer through-life service provision. Various commentators have exhorted the construction sector similarly to compete on the basis of value rather than cost. Such an aspiration resonates with notions of integrated solutions and service-led projects. It has been further argued that such ideas cannot meaningfully be considered separately from outsourcing trends within the construction industry's client base. In no small way, it was the outsourcing of asset management capabilities by newly privatised client organisations that created the space for contracting firms to expand into services. The logical next step thereafter is to offer bespoke 'solutions' that combine constructed facilities within ongoing aspects of service provision. The provision of integrated solutions which 'add value' has been argued elsewhere to comprise a radically different way for construction firms to position themselves in the marketplace. But these ideas have undoubtedly played out differently in different market sectors, and the trend towards outsourcing is by no means universal. In 
some sectors, the pattern is cyclical; periods characterised by the outsourcing of asset management capabilities are followed by periods when they are taken back in-house. Such oscillations often result from adjustments in strategy as a result of changing ownership patterns.

Particular attention has been given to the changing context of highways procurement and the shift of highway maintenance capability to the private sector. Especially significant has been the re-orientation of the Highways Agency from 'asset manager' to 'network operator'. This change has been accompanied by a commitment to work in 'collaborative partnership' with the private sector, thereby creating the space for the provision of 'solutions'. Conco Highway Solutions Limited (CHSL) has been a major beneficiary of this changing context. It has further been extremely adept at responding and adapting to a string of procurement initiatives that have sought to maximise innovative responses from the private sector. However, as significant as these changes are, they still remain a long way short of the vision whereby private sector firms compete on the basis of through-life value provision. CHSL would of course welcome any additional opportunities that enable them to compete on the basis of knowledge and innovation. But despite significant progress, the notion of 'collaborative partnership’ remains more of a rhetorical aspiration than a lived reality.

The second context to have received particular attention has been that provided by the Private Finance Initiative (PFI). Saxon’s (2002; 2005) vision of an industry based on 'value' explicitly links PFI with the provision of integrated solutions and the possibility of new business models based on life-cycle value creation. The 
establishment of PFI has undoubtedly had a major impact on the UK procurement landscape, even if the resultant benefits to the taxpayer remain heavily contested. The risks associated with first-wave PFI projects were substantial and the market in consequence sought high returns. But the market has since matured significantly, with corresponding reductions in both risk and returns. It is also somewhat disingenuous to suggest that PFI represents an entirely new business context; firms such as Conco have long-established track records in BOT-type projects with considerable experience of balancing potential risks against potential returns.

While there are dangers in extrapolating too much from a single case study, feedback from practitioners within other companies suggest that Conco is by no means unusual. What is clear is that such firms such do not radically re-orientate their businesses in response to every new procurement arrangement. In the case of PFI, the tendency has been to establish specialist teams with the appropriate expertise. Meanwhile, the rest of the business continues to operate in much of the same way as it ever did. The story is therefore less about how such firms might migrate from one business model to another and much more about how they might organise themselves such that different business models might co-exist. Radical change is simply too risky.

Aspirations of providing through-life value for clients must be balanced against responsibilities to provide returns to shareholders. And in truth, the former is only worth doing if it contributes to the latter. Otherwise investors will take their capital elsewhere. This is the nature of the marketplace; and it is the link to 
shareholder returns that provides the market incentive for innovation. Adding value for clients was a constant aspiration among managers in Conco, but this was frequently contrasted with the need to contribute to shareholder value. Certainly Saxon's (2002) vision for the construction sector based on 'adding value for customers and society’ seems to neglect the need to balance such aspirations against shareholder returns.

It has also been suggested that the 'value agenda' provides a discourse that can usefully be appropriated to legitimise changes that are already happening. It has been further suggested that the more sophisticated concepts of integrated solutions and service-led projects act as sense-making mechanisms which help practitioners deal with emergent complexity. Such ideas enable the more reflective practitioners to make sense of the changes they see happening around them; they also provide discursive resources to help them legitimise their own actions.

As a final comment, we hope we have done justice to the sophistication of thinking that we found amongst the interviewees within Conco. The construction industry is often criticised for its supposed backwardness, but this stereotype is categorically not supported by the research conducted. Ultimately, the challenges of enacting the 'value agenda' cannot simply be overcome by platitudes about collaborative working. The challenges are much more deeply rooted within the institutional context within which firms and practitioners operate. And the broader institutional context (and its justifying narratives) cannot be understood in isolation of the bigger picture rating to privatisation and outsourcing. 


\section{REFERENCES}

Alderman, N., Ivory, C.J., Vaughan, R., Thwaites, A. and McLoughlin, I.P. (2002) The project management implications of new service-led projects. Paper presented at the British Academy of Management Conference, London, 9-11 September.

ASCE. (2007) The Vision for Civil Engineering in 2025. American Society of Civil Engineers. Reston, USA.

Auguste, B.G., Harmon, E.P. and Pandit, V. (2006) The right service strategies for product companies. The McKinsey Quarterly, Issue 1, 41-51.

Bates, M. (1997) Review of the Private Finance Initiative (Public/Private Partnerships). HM Treasury, London.

Bates, M. (1999) Second review of the private finance initiative by Sir Malcolm Bates. HM Treasury, London.

Bishop, M., Kay, J. and Mayer, C. (1994) Introduction: Privatization in Performance. In: M. Bishop, J. Kay, and C. Mayer, (eds.), Privatisation and Economic Performance. Oxford University Press, Oxford. 
Brady, T., Davies, A. and Gann, D. M. (2005a) Creating value by delivering integrated solutions. International Journal of Project Management, 23, 360-365.

Brady, T., Davies, A. and Gann, D. (2005b) Can integrated solutions business models work in construction?. Building Research \& Information, 33(6), 571-579.

Cooke, F. L. (2003) Maintaining change: the maintenance function and the change process. New Technology, Work and Employment, 18(1): 35-49.

Cowan, S. (1994) Privatisation and Regulation of the Water Industry in England and Wales. In: M. Bishop, J. Kay and C. Mayer (eds), Privatisation and Economic Performance. Oxford University Press, Oxford.

Davidson, J. O. (1990) The Commercialization of Employment Relations: The Case of the Water Industry. Work, Employment and Society, December.

Davies, A. (2003). Integrated Solutions: The Changing Business of Systems Integration. In A. Prencipe, A. Davies and M. Hobday (eds). The Business of Systems Integration. Oxford University Press, Oxford.

Davies, A. (2004) Moving base into high-value integrated solutions: a value stream approach. Industrial and Corporate Change, 13(5), 727-756. 
Davies, A. and Hobday, M. (2005) The Business of Projects: Managing Innovation in Complex Products and Systems. Cambridge University Press, Cambridge.

Davies, A. and Salter, A. (2006) The Great Experiment: Public-private partnerships and innovation in design, production and operation of capital goods in the UK. In M.D. McKelvey and M. Holmén (eds). Flexibility and Stability in the Innovating Economy, Oxford University Press, Oxford. pp. 73- 95.

DETR. (1998) Rethinking Construction. Department of Environment Transport and the Regions, London.

Dubois, A. and Gadde, L.-E. (2002) Systematic combining: an abductive approach to case research. Journal of Business Research, 55, 553-60.

Education and Skills Committee (2007) Sustainable Schools: Are we building schools for the future? Seventh Report of Session 2006-07, Vol. 1, House of Commons, The Stationary Office, London.

Eisenhardt, K. M (1989) Building theories from case study research, Academy of Management Review, 42, 532-50.

Eisenstat, R., Foote, N., Galbraith, J. and Milller, D. (2001) Beyond the business unit. The McKinsey Quarterly, 2001 Issue 1, 54-63. 
Flyvberg, B. (2007) Five Misunderstandings about Case-Study Research. In C. Seale, G. Gobo, J. F. Gubrium, and D. Silverman (eds), Qualitative Research Practice: Concise Paperback Edition. Sage, London, pp. 390-404.

Foote, N.W., Galbraith, J., Hope, Q. and Miller, D. (2001) Making solutions the answer. The McKinsey Quarterly, 2001 Issue 3, 84-93.

Galbraith, J.R. (2002) Organizing to Deliver Solutions. Organizational Dynamics, 31(2), 194-207.

Gebauer, H. and Friedli, T. (2005) Behavioural implications of the transition process from products to services. Journal of Business \& Industrial Marketing, 20(2), 70-78.

Hamel, G. and Prahalad, C. K. (1994) Competing for the Future. Harvard Business School Press, Boston.

Haynes, L. and Roden, N., (1999) Commercialising the management and maintenance of trunk roads in the United Kingdom. Transportation, 26(1), 31-54.

HM Treasury, (2000) Public Private Partnerships: The Governments Approach. The Stationery Office, Crown Copyright 2000, London.

HM Treasury, (2003) PFI: meeting the investment challenge. The Stationery Office, Crown Copyright 2003, London. 
HM Treasury. (2006) PFI: strengthening long-term partnerships. The Stationary Office, Crown Copyright 2006, London.

Highways Agency. (2005) Delivering Best Value Solutions and Services to Customers - HA Procurement Strategy Review 2005. Highways Agency Publications Group, Wetherby, UK.

Hobday, M. (1998) Product complexity, innovation and industrial organisation. Research Policy, 26, 689-710.

Hobday, M., Davies, A. and Prencipe, A. (2005) Systems integration: a core capability of the modern corporation. Industrial and Corporate Change, 14(6), 1109-1143.

Ivory, C., Alderman, N., McLoughlin, I. and Vaughan, R. (2006) Sense-making as a process within complex projects. In: D. Hodgson and S. Cicmil (eds), Making Projects Critical. Palgrave Macmillan, Basingstoke, UK. pp. 316-334.

Lawrence, P.R and Lorsch, J.W., (1967) Organization and Environment. Harvard University Press, Cambridge.

Leiringer, R. (2006) Technological innovation in the context of PPPs: incentives, opportunities and actions. Construction Management and Economics, 24(March), 301-308. 
Levitt, R.E. (2007) CEM research for the next 50 years: maximizing economic environmental, and social value of the built environment. Journal of Construction Engineering and Management, 133(9), 619-628.

Livesey, F. (2006) Defining High Value Manufacturing. A report for the Confederation of British Industry (CBI) and the Department of Trade and Industry (DTI). University of Cambridge Institute for Manufacturing, Cambridge.

MacMillan, I.C. and McGrath, R.G. (1997) Discovering New Points of Differentiation. Harvard Business Review, July - August, 133-145.

Miles, M.B. and Huberman, A.M. (1994) Qualitative Data Analysis: an expanded sourcebook, $2^{\text {nd }}$ edition. SAGE Publications, Thousand Oaks, USA.

Miller, D., Hope, Q., Eisenstat, R., Foote, N. and Galbraith, J. (2002) The problem of solutions: Balancing clients and capabilities. Business Horizons, March-April, 3-12.

NAO. (2007) Improving the PFI tendering process. National Audit Office, London.

Ogden, S. G. (1995) Transforming frameworks of accountability: the case of water privatization. Accounting, Organization and Society, 20(2), 193-218. 
Oliva, R. and Kallenberg, R. (2003) Managing the transition from products to services. International Journal of Service Industry Management, 14(2), 160-172.

Orton, J. D. (1997) From inductive to iterative grounded theory: zipping the gap between process theory and process data. Scandinavian Journal of Management, 13(4): 419-439.

Pettigrew, A. M. (1997) What is processual analysis?. Scandinavian Journal of Management, 13(4), 337-348.

Sawhney, M., Balasubramanian, S. and Krishnan, V.V. (2004) Creating Growth with Services. MIT Sloan Management Review, Winter, 34-43.

Saxon, R. (2002) The industry ‘formerly known as construction': an industry view of the Fairclough Review. Building Research and Information, 30(5), 334-337.

Saxon, R. (2005) Be Valuable: A guide to value in the built environment. Constructing Excellence, London.

Slywotzky, A.J. and Morrison, D.J. (1997) The Profit Zone: how strategic business design will lead you to tomorrow’s profit. John Wiley \& Sons, Chichester, UK.

Spackman, M. (2002) Public-private partnerships: lessons from the British approach. Economic Systems, 26, 283-301. 
Teece, D. J. and Pisano, G. (1994) The dynamic capabilities of firms: an introduction. Industrial Corporate Change, 3(3): 537-556.

Teece, D. J., Pisano, G. and Shuen, A. (1997) Dynamic capabilities and strategic management. Strategic Management Journal, 18(7), 509-533.

Thiry, M. (2001) Sensemaking in value management practice. International Journal of Project Management, 19(2), 71-77.

Thomas, J. (2000) Making sense of project management. In R. A. Lundin and F. Hartman (eds), Projects as Business Constituents and Guiding Motives, Kluwer Academic, Norwell, MA. pp. 25-43.

Tsoukas, H. and Chia, R. (2002) On Organizational becoming: rethinking organizational change. Organization Science, 13(5), 567-582.

Tranfield, D., Rowe, A., Smart, P.K., Levene, R., Deasley, P. and Corley, J. (2005) Coordinating for service delivery in public-private partnership and private finance initiative construction projects: early findings from an exploratory study. Proceedings of the Institution of MechanicalEngineers, Vol. 219, Part B, Journal of Engineering Manufacture. 165-175.

Vandermerwe, S. and Rada, J. (1988) Servitization of business: Adding value by adding services. European Management Journal, 6(4), 314-324. 
Weick, K. E. (2001) Making Sense of the Organization, Blackwell, London.

Wise, R. and Baumgartner, P. (1999) Go Downstream: The New Profit Imperative in Manufacturing. Harvard Business Review, September-October, 133-141. 


\section{END NOTES}

1) Transfer of Undertakings (Protection of Employment) Regulations 